doi: 10.7546/BL.LXV.18.03.09

\author{
АКЦИОННИ ИМЕНА С ОБЩИ ГРЬЦКИ ОСНОВИ \\ В БЪЛГАРСКИЯ И РУМЬНСКИЯ ЕЗИК \\ ВЛАДИСЛАВ МАРИНОВ \\ ВЕЛИКОТЬРНОВСКИ УНИВЕРСИТЕТ „СВ. СВ. КИРИЛ И МЕТОДИЙ“ \\ w.marinov@uni-vt.bg \\ НАТАЛИЯ СОТИРОВА \\ ЮГОЗАПАДЕН УНИВЕРСИТЕТ „НЕОФИТ РИЛСКИ“ - БЛАГОЕВГРАД \\ natalia.sotirova@abv.bg
}

\title{
NOMINA ACTIONIS WITH AN IDENTICAL GREEK ROOT IN BULGARIAN AND ROMANIAN
}

VLADISLAV MARINOV

"St. Cyril AND St. Methodius" University of Veliko TARNOVO

w.marinov@uni-vt.bg

NATALIYA SOTIROVA

SOUTH-WEST UNIVERSITY “NEOFIT RILSKI” - BLAGOEVGRAD

natalia.sotirova@abv.bg

This paper studies a group of deverbal abstract nouns in Bulgarian and Romanian that share identical roots of Greek origin. It traces the adaptation and assimilation of some Greek borrowings in Bulgarian that have become part of the Romanian vocabulary through Bulgarian. Their integration in the word-formation systems of both languages indicates the final stage of their assimilation and their new derivatives are studied in two aspects: a) synchronically - as part of the contemporary lexical system of the two Balkan languages and b) diachronically - considering their Greek root.

Keywords: Greek borrowings, complex method, Nomina Actionis, hybrid formations, Geek roots, Bulgarian suffixes, Romanian suffixes

Влиянието на гръцкия език върху българския е доста старо и продължително. Както посочва К. Мирчев (вж. Мирчев/Mirchev 1978), то се е отразило предимно върху лексикалната система въпреки възможностите, които са предоставяли и други езикови равнища. Като естествен резултат от многовековния непосредствен контакт между двата езика в български навлизат значителен брой гръцки лексикални елементи.

Кирил Мирчев отбелязва, че „влиянието, което упражнява българският език върху румънския, е доста старо, доста продължително и необикновено силно“ (Мирчев/Mirchev 1978: 78). Отдавна е установено, че значителна част от лексикалния състав на румънския език е от български произход, а заедно с чисто българските думи в румънски навлизат и много гръцки за- 
емки, вече адаптирани на българска почва (Цонев/Tsonev 1984: 143). Този факт е подчертан и от множество румънски учени като А. Д. Ксенопол, Ов. Денсушану, Ал. Росети, Х. Михайеску и др., които отчитат ролята на православието и на старобългарския език за опосредственото навлизане на гръцка лексика в румънския език (вж. Rosetti 1978; Mihăescu 1966). Тези изследователи отбелязват, че поради териториалната отдалеченост между Римската и Византийската империя повечето от гръцките лексикални елементи преминават с посредничеството на славянския (старобългарския) език.

В процеса на лексикалното заемане, когато от един език в друг прониква значителен брой думи, се извършват два процеса, известни като морфологична адаптация и словообразувателна асимилащия. Пьрвият е свързан с подвеждането на чуждите думи към определени лексико-граматични типове и с адаптирането им към присъщите домашни граматически категории. Във втория случай одомашнените заемки вече се превръщат в произвеждащи основи, които започват да се свързват с домашни словообразувателни форманти, като по този начин участват в т.нар. хибридно словообразуване (Кювлиева/Kyuvlieva 1980: 87). При него лексемата вече не се възприема като чуждица от носителите на езика, т.е тя следва словообразувателните модели на езика приемник и безпрепятствено образува около себе си лексикално гнездо (Лютакова/Lyutakova 1997: 6). Новите лексеми, съставени от разноезични елементи, в словообразувателен аспект имат хибриден характер (Сотирова-Милчева/Sotiorva-Milcheva 2016: 9).

Обект на анализ тук не са всички субстантивни хибриди, представляващи абстрактни девербални формации, а само тези, които са образувани с еднакви гръцки основи и съответно с български и румънски суфикси.

Това изследване е част от по-обхватен труд, посветен на хибридните субстантиви с гръцки основи, където те се разглеждат двупланово: а) синхронно - като част от сьвременната лексикална система на двата балкански езика, понеже са образувани в резултат от процесите на адаптация и асимилация на грьцките заемки в тях, и б) диахронно - при разкриване на общата грьцка основа. Включването на грьцките елементи в словообразувателните системи на двата езика и на диалектно, и на книжовно равнище е показател за крайната степен на асимилация в тях, а новите им производни могат да бъдат изследвани с методите на синхронното словообразуване, тъй като вече е налице вторична прозрачност поради създалата се широка връзка с други, еднаквокоренни думи с формирани обемни словообразувателни гнезда. Според Докулил именно „мотивацията и в други думи, идващи от корена, е условие за прилагане на синхронния подход“" (Dokulil 1962: 208-210).

За диахронния анализ е приложен подход, чрез който непрозрачната гръцка основа получава яснота. Във връзка с това са използвани следните етимологични речници: Български етимологичен речник (БЕР). Том 1-8. София, АИ „Проф. Марин Дринов“ (1971-2017); Младенов, Ст. Етимоло- 
гически и правописенъ речникъ на българския книжовенъ езикъ. София (1941); Филипова-Байрова, М., С. Бояджиев, Ел. Мамалова, К. Костов. Речник на чуждите думи в българския език. София (1982), а също така и трудът на $М$. Филипова-Байрова „Гръцки заемки в съвременния български език“. Използвани са и изследванията на Mihăescu, $H$. Influenţa grecească asupra limbii române pîna în secolul al XV-lea. Bucureşti (1966) и Rosetti, Al. Istoria limbii române. I. De la origini pînă în secolul al XVII-lea. Ediţia a doua revăzută şi adăugită. Bucureşti (1978), посветени на гръцките заемки в румънския език. За дефиниране на лексикалното значение на румънските лексеми се използва онлайн корпусът с румънски речници на https://exon line.ro/.

Част от хибридните названия за действия, разгледани тук, в по-малка или в по-голяма степен могат да се употребяват и като резултативни, като тези случаи се отбелязват в словообразувателната парафраза на съответната формация.

Пример в българския език за такива субстантивни хибриди, които могат да означават и самото действие, а също така и резултата от процеса, е формацията прокопсѝя със значения: 1) 'преуспяване', но и 2) 'сполука,

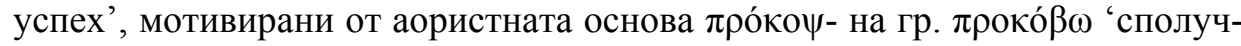
вам, напредвам, успявам'. В румънски подобен случай представя формацията tipăríre: 1) 'действието печатане', но и 2) 'резултатьт от него'; срв. глагола tipări ‘печатам' < tipăr 'печат, отпечатьк, модел', заемка от гр.

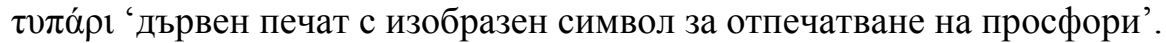

Тъкмо въз основа на идентичната им форма в сравнително голям брой от случаите, но и поради еднаквата им ономасиологична мотивираност, както и предвид невъзможността при повечето от облиците да се прокара рязка граница между действието и неговия резултат, редица автори разглеждат акционните и резултативните имена в рамките на една категория (Szymański 1968; Кочев/Kochev 1972; Домусчиева/Domuschieva 1999; Mocтрова/Mostrova 1989; Перчеклийски/Perchekliyski 2011; Кочев и др./Kochev et al. 1980: 135).

В тази работа, в рамките на ономасиологично мотивираната девербална абстрактна лексика, като се има предвид контекстовата употреба на анализираните акционни имена с общи гръцки основи в български и румънски, се посочва и резултативното значение, което имат някои от тях.

\section{В българския език}

Имена от женски род

1. Н а с т а в к а -йя:

залисия 'действието залисване, объркване, замайване', но и 'резултат от действието залисване, шум, глъчка', мотивирано от глагола залй-

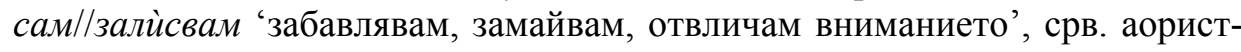

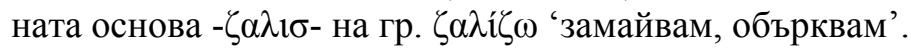


прокопсѝя 'действието прокоेпсване, преуспяване', но и 'резултат от действието проко̀псване, сполука, успех', мотивирано от глагола проко̀n-

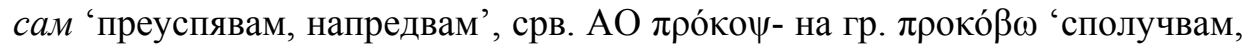
напредвам, успявам'.

2. Н а с т а в к а -ост:

залйсаност 'действието залисване, объркване, замайване', обусловено от глагола залйсам 'забавлявам, замайвам, отвличам вниманието', срв.

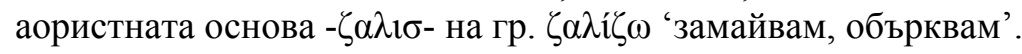

\section{Имена от среден род}

3. Н а с т а в к а -не (-ане, -ене):

анатемиेсване//анатемоेсване 'действието проклинане', но и 'резултат от действието проклинане - проклятие', мотивирано от глагола анатемйс-

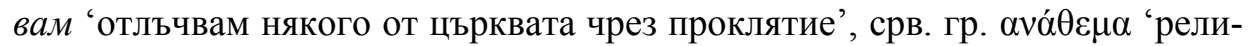
гиозен дар', в християнско време развива значение 'проклятие, клетва'.

арга̀сване 'действието обработване на кожа', мотивирано от глагола

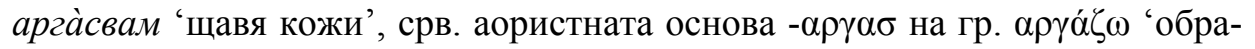
ботвам кожа'.

афорѐсване 'действието отлъчване', мотивирано от глагола афорѐсвам

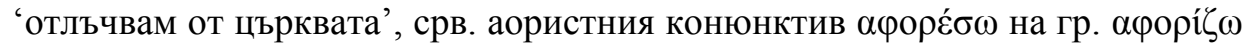
'отстранявам'.

вàncване 'багрене, боядисване', действие, мотивирано от глагола ва̀nc-

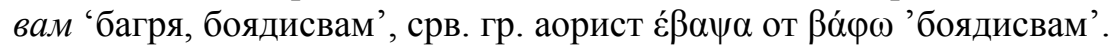

даскалу̀ване 'действие, мотивирано от глагола даскалуввам', срв. гр. $\delta \alpha ́ \sigma \kappa \alpha \lambda о \varsigma$ 'учител'.

дърмонѐне 'действие, обусловено от глагола дърмоня 'пресявам нещо с

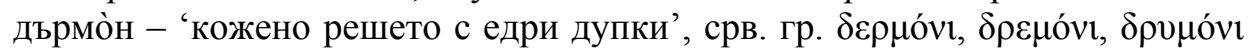
също.

залисване 'действието объркване, замайване', обусловено от глагола залйсам 'забавлявам, замайвам, отвличам вниманието', срв. аористната

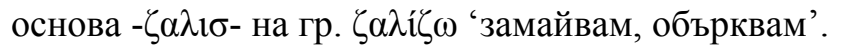

захаросване 'действие, мотивирано от глагола захаросвам, срв. аорист-

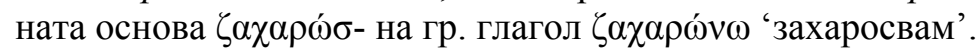

икономисване 'действието спестяване', мотивирано от глагола икономисвам, срв. аориста оюкобо́ $б \sigma \alpha$ на гр. глагол оюкоvоню́ 'икономисвам, пестя'.

кивернйсване 'уреждане, оправяне, управляване', действие, мотивирано от глагола кивернйсвам 'уреждам, оправя, управлявам', срв. аористната

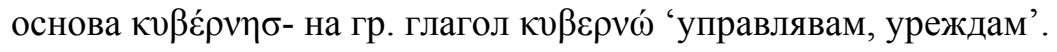

липсване 'действие, обусловено от глагола липсвам, срв. аориста є́ $\lambda \varepsilon \imath \alpha \alpha$ на гр. $\lambda \varepsilon i ́ \pi \omega$ 'липсвам’.

молѐпсване 'заразявам, предавам болест', действие, обусловено от глагола молѐпсвам 'заразявам с болест', срв. аористната основа $\mu$ о́ $\varepsilon \psi-$ на гр. $\mu о \lambda \varepsilon v ́ \omega$ 'замърсявам, заразявам'. 
орѝсване 'определяне, предсказване', действие, обусловено от глагола орйсвам 'определям живота на някого, предсказвам', срв. аористните форми $\omega \rho \iota \sigma \alpha$, ó

паря̀сване 'напускане, изоставяне', действие, мотивирано от глагола паря̀свам 'напускам, изоставям', срв. аориста $\pi \alpha \rho \alpha \varepsilon i ́ \alpha \sigma \alpha$ на гр. гл. $\pi \alpha-$

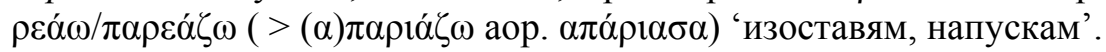

педѐnсване 'възпитаване, наказване', действие, мотивирано от глагола педѐnсвам 'уча, възпитавам, наказвам', срв. аориста $\pi \alpha i ́ \delta \varepsilon \psi \alpha$ на гр. глагол $\pi \alpha 1 \delta \varepsilon v ́ \omega$ 'възпитавам, измъчвам, наказвам'.

поевтиняване 'действие, мотивирано от глагола поевтинявам' < евтин,

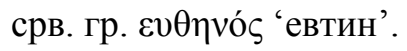

проко̀псване//проко̀псвание остар. книж. 'действието преуспяване', мотивирано от глагола проко̀сам 'преуспявам, напредвам', срв. аориста

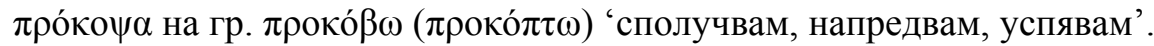

сосване 'действие, мотивирано от глагола со̀свам 'уморявам се, изтощавам се, стигам, достатъчен съм’, срв. аористния конюнктив бஸ́бю на гр.

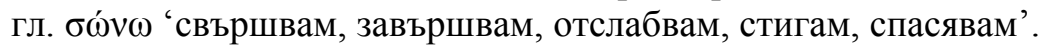

типаро̀сване 'действието изографисване', мотивирано от глагола $m u$ -

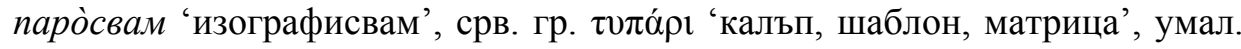
от ти́ло 'образец, модел, форма, печат'.

троня̀сване 'възкачване на трон' действие, обусловено от глагола тро-

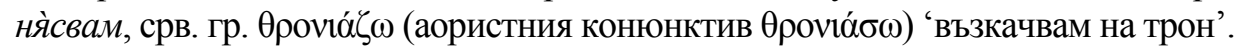

харакоेсване 'действие, мотивирано от глагола харако̀свам, харако̀сам

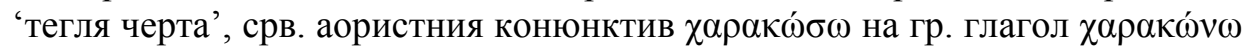

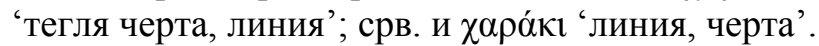

\section{В румънския език}

\section{Имена от женски род}

1. Н а с т а в к а -eală:

argăseálă 'арга̀сване, обработване на кожа', действие, мотивирано от глагола argăsi 'арга̀свам, щавя кожи', срв. аористната основа $-\alpha \rho \gamma \alpha \sigma$ на гр. $\propto \rho \alpha \dot{\zeta} \omega$ 'обработвам кожа'.

chiverniseálă 'администриране, управляване', действие, обусловено от глагола chivernisí 'администрирам, управлявам', срв. аористната основа

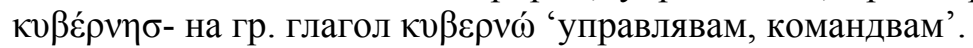

molipseálă 'заразяване', действие, мотивирано от глагола molipsi 'зара-

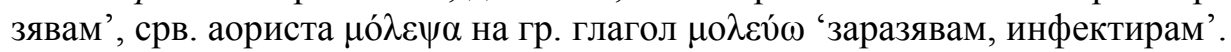

pricopseálă 'действието проко̀псване, преуспяване', но и резултатьт от него, мотивирано от глагола pricopsi 'прокоेпсам, преуспявам, напредвам',

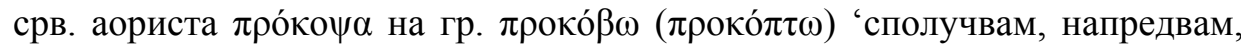
успявам'.

tipăreală 'действието печатане и резултатът от него', обусловено от глагола tipări ‘печатам' < tipăr ‘печат, отпечатък, шаблон, кройка, матрица, 


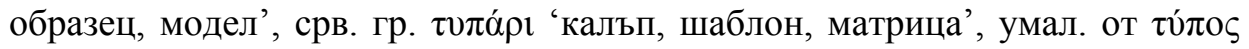
'образец, модел, форма, печат'.

târnoseálă 'освещаване на църква', действие, мотивирано от глагола

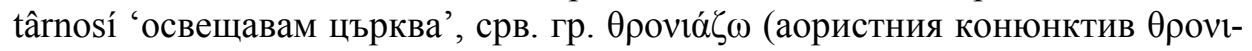
$\alpha ́ \sigma \omega)$ 'поставям на трон, разполагам; освещавам църква'.

văpseală 'багрене, боядисване', действие, мотивирано от глагола vopsi

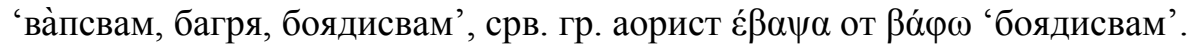

2. Н а с т а в к а-anie:

târnosánie 'освещаване на църква', действие, мотивирано от глагола

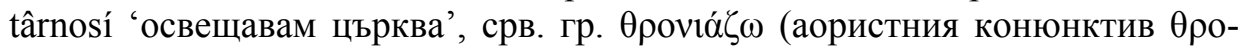
vió $\sigma \omega)$ 'поставям на трон, разполагам; освещавам църква'.

3. Н а с т а в к а -enie:

afurisénie 'действието отлъчване, афорѐсване', мотивирано от глагола afurisi 'отльчвам от църквата', срв. аористната основа $\alpha \varphi \rho_{\rho} \sigma \alpha$ на гр.

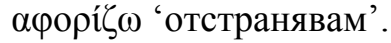

4. Н а с т а в к а -íre:

afurisire 'действието отльчване, афорѐсване', мотивирано от глагола

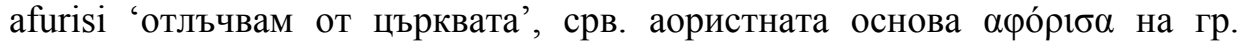
арорі́б 'отстранявам'.

anatematisire 'действието анатемйсване, проклинане', но и 'резултат от действието проклинане - проклятие', мотивирано от глагола anatem(at)isi 'анатемйсвам, отлъчвам някого от църквата чрез проклятие', срв. гр. $\alpha v \alpha ́-$ $\theta \varepsilon \mu \alpha$ 'религиозен дар', в християнско време развива значение 'проклятие, клетва'.

arăcire 'действие, мотивирано от глагола arăcí 'поставям хара̀ци, колове за подпиране на лозе и др. растения' < (h)arác 'харак', срв. гр. $\chi \alpha \rho \alpha ́ к 1$ 'линия, черта'.

argăsíre 'арга̀сване, обработване на кожа', действие, мотивирано от

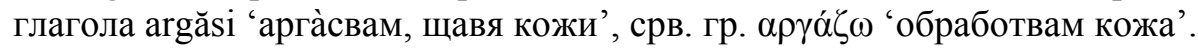

chivernisire 'администриране, управляване', действие, обусловено от

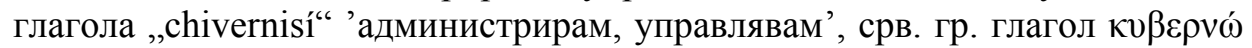
'управлявам, командвам'.

dăscălíre 'даскалу̀ване', действие, мотивирано от глагола dăscălí 'дас-

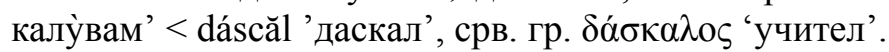

dârmonire 'дърмонене', действие, мотивирано от глагола dârmoní 'пресявам с дърмо̀н' < „dârmon“ 'дърмо̀н, кожено решето с едри дупки’, срв.

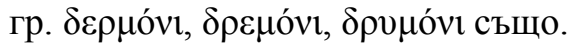

economisire 'икономисване', действие, мотивирано от глагола есоnomisí 'икономисвам', срв. аориста окоvó $\mu \eta \sigma \alpha$ на гр. глагол оюкоvонб́ 'икономисвам'.

ieftinire 'поевтиняване', действие, мотивирано от глагола ieftiní 'поевтинявам' < iéftin 'евтин', срв. гр. вvөпvó ` 'евтин'.

lipsíre 'липсване', ‘действие, обусловено от глагола lipsi 'липсвам',

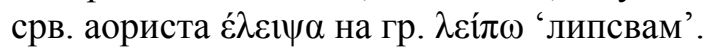


molipsire 'заразяване', действие, мотивирано от глагола molipsi 'заразявам', срв. аористната основа $\mu$ о́ $\varepsilon \varepsilon-$ на гр. глагол $\mu о \lambda \varepsilon v ́ \omega$ 'заразявам, инфектирам'.

părăsire 'паря̀сване, напускане, изоставяне', действие, мотивирано от глагола părăsí 'паря̀свам, напускам, изоставям’, срв. аориста $\pi \alpha \rho \alpha \varepsilon i ́ \alpha \sigma \alpha$ на

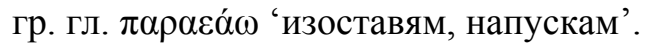

pedepsire 'наказване, осъждане', действие, мотивирано от глагола реdepsi 'наказвам, осъждам', срв. аориста $\pi \alpha i ́ \delta \varepsilon \psi \alpha$ на гр. глагол $\pi \alpha 1 \delta \varepsilon v ́ \omega$ 'възпитавам, измъчвам, наказвам'.

procopsirel/pricopsíre проко̀nсване 'действието преуспяване', мотивирано от глагола pricopsi 'прокопсам, постигам добро материално положе-

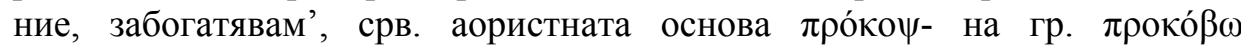
(

sosire 'стигане, пристигане', действие, мотивирано от глагола sosí 'сти-

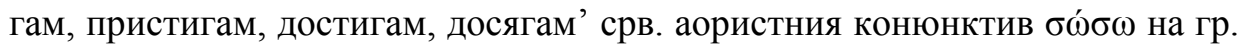

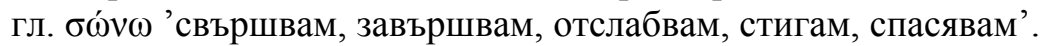

stivuíre 'стива̀сване', действие, мотивирано от глагола stivuí 'стива̀свам, редя, натрупвам, разбивам' < stívă 'куп предмети от един вид с приблизително еднакви размери (дърва, тухли и др.), срв. гр. бтоí $\beta \alpha$ 'куп, купчина'.

târnosire 'освещаване на църква', действие, мотивирано от глагола târ-

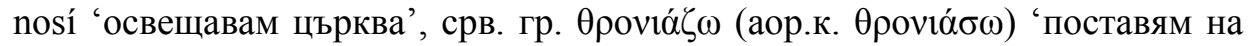
трон, разполагам', в част от употребите - със специализация на значението 'поставям' > 'освещавам', възникнало най-вероятно в гръцки.

tipăríre 'действието печатане и резултатьт от него', обусловено от глагола tipări ‘печатам' < tipăr 'печат, отпечатък, шаблон, кройка, матрица,

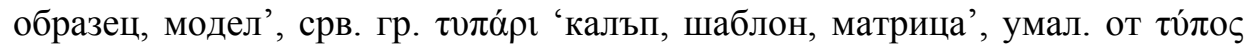
'образец, модел, форма, печат'.

vopsire 'багрене, боядисване', действие, мотивирано от глагола vopsi

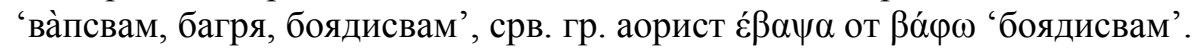

ursire 'орисване, определяне съдбата на някого', действие, мотивирано от глагола ursí 'определям съдбата на някого', срв. аористните форми б́рє-

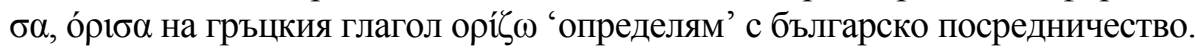

zaharisire 'действието захаросване', мотивирано от глагола zaharisi

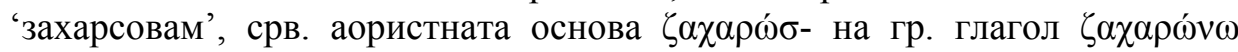
'захаросвам'.

zalisire 'действието объркване, смущаване, досаждане, мотивирано от глагола zalisí 'обърквам се, смущавам се', срв. срв. аористната основа

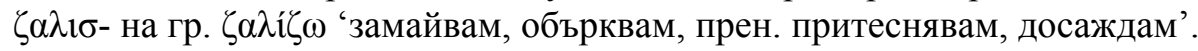

\section{ИЗВОДИ}

Разглежданите акционни формации с хибриден характер са мотивирани главно от глаголи, проникнали чрез аористния облик на съответния гръцки глагол. Аористната основа, която за българите не е прозрачна и яс- 
на, се възприема като „сегашна“, а аористният показател -б- се запазва и в мотивираните от тях отглаголни съществителни. В румънския език глаголите от гръцки, навлезли чрез българския език от старобългарския период, са предимно в парадигмата на IV спрежение, където е и останалата славянска лексика (вж. повече у Маринов/Marinov 2013: 169). Там попада както лексиката, заета по книжовен път (предимно религиозна и административна лексика), така и лексиката, използвана във всекидневното битово общуване. Не са малко и отглаголните съществителни, образувани от деноминативни глаголи - заемки от гръцки език (анатематйсване/aнатемйсване 'проклинане', < анатемйсвам, anatematisíre 'действието анатемйсване, проклинане', мотивирано от глагола anatem(at)isi, срв. гр. $\alpha v \alpha ́ \theta \varepsilon \mu \alpha$ 'проклятие, клетва'; даскалу̀ване 'действие, мотивирано от глагола даскалу̀вам', dăscălíre 'даскалу̀ване' < dăscălí 'даскалу̀вам' < dáscăl 'даскал', срв.

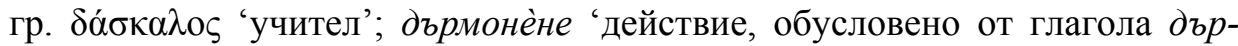
моня, пресявам нещо с дърмо̀н 'кожено решето с едри дупки', dârmoníre

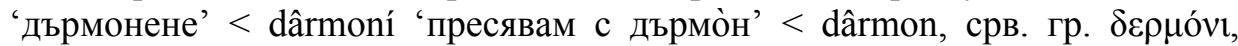

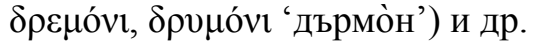

При някои от тях може да се говори за известна резултативност, като се има предвид контекстовата им употреба (залисйя 'действието залисване, объркване, замайване', но и 'резултат от действието залисване, шум, глъчка'; pricopseálă 'действието прокопсване, преуспяване, но и резултатът от него).

Най-богат откъм представители в българския език е словообразувателният тип със суфикс -не. В румънски разнообразието е по-голямо (-eală, -anie, -enie, -íre), а най-продуктивен е словообразувателният тип със суфикс -íre.

Разгледаните субстантивни хибриди в българския език са предимно от среден род, ограничен брой са женските имена, а в румънски всички хибридни акционни формации са от женски род.

\section{ЛИТЕРАТУРА}

Домусчиева 1999: Домусчиева, Л. Сложни имена за действия и за резултати от действия от ж.р. в българските говори. - В: Актуални проблеми на българското словообразуване. София, УИ „Св. Климент Охридски“, с. 252-263.

Кочев 1972: Кочев, Ив. Диалектни категории и типове при словообразуването на съществителното име (съпоставително изследване върху материал от три български говора). - Известия на Института за български език, кн. 20, с. 107-185.

Кочев и др. 1980: Кочев, Ив., Ем. Кочева, Т. Мострова. Словообразуване на съществителното име в Супрасълския сборник. - В: Проучвания върху Супрасълския сборник. София, Издателство на БАН.

Кювлиева 1980: Кювлиева, B. Морфологична адаптация и асимилация на турските заемки - съществителни и прилагателни - в българския език. - Известия на Института за български език, кн. 24, с. 78-136. 
Лютакова 1997: Лютакова, Р. Морфологична адаптация на английските заемки в българския и румънския език. - Съпоставително езикознание, XXII, 2, c. 5-18.

Маринов 2013: Маринов, Вл. Хибридни глаголи във влашкия диалект в гр. Брегово (Видинско). - В: Путеви и домети дијалекатске лексикографије. Ниш, с. 167-177.

Мирчев 1978: Мирчев, К. Историческа граматика на българския език. III изд. София, Наука и изкуство.

Мострова 1989: Мострова, $T$. Имена за действия и за резултати от действия в два превода от XIV в. - Език и литература, кн. 2, с. 52-58.

Перчеклийски 2011: Перчеклийски, Л. Словообразуване на Nomina abstracta в евангелски паметници от X и XI век. Благоевград, УИ „Неофит Рилски“.

Сотирова-Милчева 2016: Сотирова-Милчева, Н. Българо-грьцки лексикални хибриди (съществителни имена). Дисертация за присъждане на образователната и научна степен „доктор“. Благоевград.

Филипова-Байрова 1969: Филипова-Байрова, М. Гръцки заемки в съвременния български език. София, Издателство на БАН.

Цонев 1984: Цонев, Б. История на българския език. Том втори. А. Обща част. Б. Специални части. София, Наука и изкуство.

Dokulil 1962: Dokulil, M. Tvoření slov v češtině. T.I. Praha, Nakl. Československé akademie věd.

Mihăescu 1966: Mihăescu, $H$. Influenţa grecească asupra limbii române pîna în secolul al XV-lea. Bucureşti, Editura Academiei Republicii Socialiste Romania.

Rosetti 1978: Rosetti, Al. Istoria limbii române. I. De la origini pînă în secolul al XVII-lea. Ediţia a doua revăzută şi adăugită. Bucureşti, Editura Științifică și Enciclopedică.

Szymański 1968: Szymański, T. Słowotworstwo rzeczownika w bułgarskich tekstach XVII-XVIII wieku. Wrocław - Warszawa - Krakow, Zakład Narodowy im. Ossolińskich, 71-118.

\section{REFERENCES}

Dokulil 1962: Dokulil, M. Tvoření slov v češtině. T.I. Praha, Nakl. Československé akademie věd.

Domuschieva 1999: Domuschieva, L. Slozhni imena za deystviya i za rezultati ot deystviya ot zh.r. v balgarskite govori [Compound Feminine Nouns for Actions and Action Results in Bulgarian Dialects]. - In: Aktualni problemi na balgarskoto slovoobrazuvane [Current Issues in Bulgarian Word Formation]. Sofia, UI „Sv. Kl. Ohridski“, 252-263].

Filipova-Bayrova 1969: Filipova-Bayrova, M. Gratski zaemki v savremenniya balgarski ezik [Greek Borrowings in Modern Bulgarian]. Sofia, Izdatelstvo na BAN.

Kochev 1972: Kochev, Iv. Dialektni kategorii i tipove pri slovoobrazuvaneto na sashtestvitelnoto ime (sapostavitelno izsledvane varhu material ot tri balgarski govora) [Dialect Categories and Types in the Word Formation of Nouns (Com- 
parative Study on Three Bulgarian Dialects)]. - Izvestiya na Instituta za balgarski ezik, kn. 20, 107-185.

Kochev et al. 1980: Kochev, Iv., Em. Kocheva, T. Mostrova. Slovoobrazuvane na sashtestvitelnoto ime v Suprasalskiya sbornik [Word Formation of Nouns in the Codex Suprasliensis]. - In: Prouchvaniya varhu Suprasalskiya sbornik [Surveys on Codex Suprasliensis]. Sofia, Izdatelstvo na BAN.

Kyuvlieva 1980: Kyuvlieva, V. Morfologichna adaptatsiya i asimilatsiya na turskite zaemki - sashtestvitelni i prilagatelni - v balgarskiya ezik [The Morphological Adaptation and Assimilation of Turkish Borrowings - Nouns and Adjectives in Bulgarian]. - Izvestiya na Instituta za balgarski ezik, kn. 24, 78-136.

Lyutakova 1997: Lyutakova, $R$. Morfologichna adaptatsiya na angliyskite zaemki v balgarskiya i rumanskiya ezik [The Morphological Adaptation of English Borrowings in Bulgarian and Romanian]. - Sapostavitelno ezikoznanie, XXII, 2, Sofia, 5-18.

Marinov 2013: Marinov, Vl. Hibridni glagoli vav vlashkiya dialekt v gr. Bregovo (Vidinsko) [Hybrid Verbs in the Wallachian Dialect in Bregovo (Vidin Region)]. - In: Putevi i dometi dijalekatske leksikografije [Methods and Scope of Dialectal Lexicography]. Nish, 167-177.

Mihăescu 1966: Mihăescu, H. Influenţa grecească asupra limbii române pîna în secolul al XV-lea. Bucureşti, Editura Academiei Republicii Socialiste Romania.

Mirchev 1978: Mirchev, K. Istoricheska gramatika na balgarskiya ezik [Historical Grammar of Bulgarian]. III $^{\text {th }}$ edition. Sofia, Nauka i izkustvo.

Mostrova 1989: Mostrova, T. Imena za deystviya i za rezultati ot deystviya v dva prevoda ot XIV v. [Nouns for Actions and Action Results in Two Translations from the XIV Century]. - Ezik i literatura, kn. 2, 52-58.

Perchekliyski 2011: Perchekliyski, L. Slovoobrazuvane na Nomina abstracta v evangelski pametnitsi ot X i XI vek [Word Formation of Nomina Abstracta in Evangelical Scripts from the $\mathrm{X}$ and XI century]. Blagoevgrad, UI "Neofit Rilski”.

Rosetti 1978: Rosetti, Al. Istoria limbii române. I. De la origini pînă în secolul al XVII-lea. Ediţia a doua revăzută şi adăugită. Bucureşti, Editura Ştiinţifică şi Enciclopedică.

Sotirova-Milcheva 2016: Sotirova-Milcheva, N. Balgaro-gratski leksikalni hibridi (sashtestvitelni imena) [Bulgarian-Greek Lexical Hybrids (Nouns)]. Disertatsiya za prisazhdane na obrazovatelnata i nauchna stepen ,doktor“. Blagoevgrad.

Szymański 1968: Szymański, T. Słowotworstwo rzeczownika w bułgarskich tekstach XVII-XVIII wieku. Wrocław - Warszawa - Krakow, Zakład Narodowy im. Ossolińskich, 71-118.

Tsonev 1984: Tsonev, B. Istoriya na balgarskiya ezik. Tom vtori. A. Obshta chast. B. Spetsialni chasti. [History of Bulgarian. Volume Two. A. General Part. B. Special Parts]. Sofia. Nauka i izkustvo. 


\section{ИЗТОЧНИЦИ / SOURSES}

БЕР: Български етимологичен речник. Том 1-8. София, Изд. на БАН, 1971-. [BER: Balgarski etimologichen rechnik. Tom 1-8. Sofia, Izd. na BAN, 1971-.]

Доп. БРНГ: Панчев, Т. Допълнение на българския речник от Н. Геров, София, Български писател, 1978. [Dop. BRNG: Panchev, T. Dopalnenie na balgarskiya rechnik ot N. Gerov. Sofia, Balgarski pisatel, 1978.]

ЕПРБКЕ: Младенов, $\mathrm{Cm}$. Етимологически и правописенъ речникъ на българския книжовенъ езикъ. София, Книгоиздателство „Хр. Г. Данов“, 1941. [EPRBKE: Mladenov, St. Etimologicheski i pravopisen rechnik na balgarskiya knizhoven ezik. Sofia, Knigoizdatelstvo „Hr. G. Danov“, 1941.]

РБЕ: Геров, Н. Речник на българския език. Т. 1-5. София, Български писател, 1975-1978. [RBE: Gerov, N. Rechnik na balgarskiya ezik. T. 1-5, Sofia, Balgarski pisatel, 1975-1978.]

РЧДБЕ: Филипова-Байрова, М., С. Бояджиев, Ел. Машалова, К. Костов. Речник на чуждите думи в българския език. София, Издателство на БАН, 1982. [RChDBE: Filipova-Bayrova, M., S. Boyadzhiev, El. Mashalova, K. Kostov. Rechnik na chuzhdite dumi v balgarskiya ezik. Sofia, 1982.]

DEXonline Dicționare ale limbii române. $<$ https://dexonline.ro/>.

\section{ПРИЛОЖЕНИЕ}

Списък с акционните хибридни форми в българския и румънския език с общи грьцки основи

\begin{tabular}{|c|c|c|}
\hline $\begin{array}{c}\text { Грыцка } \\
\text { мотивираща } \\
\text { лексема } \\
\end{array}$ & $\begin{array}{c}\text { Акционна хибридна } \\
\text { формация в } \\
\text { българския език } \\
\end{array}$ & $\begin{array}{c}\text { Акционна хибридна } \\
\text { формация в } \\
\text { румънския език } \\
\end{array}$ \\
\hline$\alpha v \alpha ́ \theta \varepsilon \mu \alpha$ & анатемйсване & anatematisire \\
\hline$\alpha \rho \gamma \alpha ́ \zeta \omega$ & арга̀сване & argăseálă, argăsire \\
\hline$\alpha \varphi \rho^{\prime}{ }^{\prime} \zeta \omega$ & афорѐсване & afurisénie, afurisire \\
\hline$\beta \alpha ́ \varphi \omega$ & ва̀псване & văpseală, vopsíre \\
\hline$\delta \alpha ́ \sigma \kappa \alpha \lambda \mathrm{o}$ & даскалуване & dăscălíre \\
\hline$\delta \varepsilon \rho \mu$ óvı & дърмонѐне & dârmonire \\
\hline 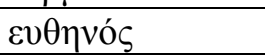 & поевтиняване & ieftinire \\
\hline$\zeta \alpha \lambda i \zeta \omega$ & $\begin{array}{l}\text { залисйя, залйсаност, } \\
\text { залисване }\end{array}$ & zalisire \\
\hline$\zeta \alpha \chi \alpha \rho \omega ́ v \omega$ & захаросване & zaharisire \\
\hline оикоуони́ & икономисване & economisire \\
\hline$\kappa v \beta \varepsilon \rho \vee \omega ́$ & кивернйсване & $\begin{array}{l}\text { chiverniseálă, } \\
\text { chivernisíre }\end{array}$ \\
\hline$\lambda \varepsilon i ́ \pi \omega$ & липсване & lipsíre \\
\hline$\mu \mathrm{o} \lambda \varepsilon v ́ \omega$ & молѐпсване & molipseálă, molipsíre \\
\hline 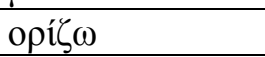 & орйсване & ursire \\
\hline$\pi \alpha \rho \alpha \varepsilon \alpha ́ \omega$ & паря̀сване & părăsíre \\
\hline
\end{tabular}




\begin{tabular}{|c|c|c|}
\hline$\pi \alpha 1 \delta \varepsilon v ́ \omega$ & педѐпсване & pedepsíre \\
\hline$\varepsilon v \theta \eta v o ́ s$ & поевтиняване & ieftinire \\
\hline 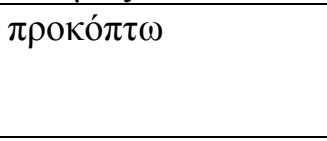 & $\begin{array}{l}\text { прокопсйя, } \\
\text { проко̀псване }\end{array}$ & $\begin{array}{l}\text { pricopseálă, } \\
\text { procopsire } \\
\text { procopsire }\end{array}$ \\
\hline$\sigma \omega ́ v \omega$ & со̀сване & sosire \\
\hline$\tau v \pi \alpha ́ \rho 1$ & типаро̀сване & tipăreală, tipăríre \\
\hline$\theta \rho o v i \alpha ́ \zeta \omega$ & троня̀сване & $\begin{array}{l}\text { târnoseálă, } \\
\text { târnosánie, târnosíre }\end{array}$ \\
\hline$\chi \alpha \rho \alpha ́ \kappa 1-\chi \alpha \rho \alpha \kappa \omega ́ v \omega$ & харако̀сване & arăcire \\
\hline
\end{tabular}

\section{РЕЗЮМЕ}

В статията се разглеждат група девербални абстрактни съществителни в българския и в румънския език с общи гръцки основи. Проследява се пьтят на адаптация и асимилация на някои гръцки заемки в български, преминали и в речниковия фонд на румънския език с българско посредничеството. Включването им в словообразувателните системи на двата езика е показател за крайната степен на асимилацията им, а новите им производни се разглеждат двупланово: синхронно като част от съвременната лексикална система на двата балкански езика, и диахронно - при разкриване на общата гръцка основа.

Ключови думи: гръцки заемки, комплексен метод, акционни имена, хибридно словообразуване, гръцки основи, български суфикси, румънски суфикси

\section{$\triangle$ Дои. д-р Владислав Маринов}

Катедра по съвременен български език, Филологически факултет Великотърновски университет „Св. св. Кирил и Методий“ ул. Т. Търновски, 2, 5000 В. Търново, България.

$\triangle$ Assoc. Prof. Vladislav Marinov, PhD Department of Modern Bulgarian language "St. Cyril and St. Methodius" University of Veliko Tarnovo 2 T. Turnovski str. 5003 Veliko Tarnovo, Bulgaria

\section{$\triangle$ Д-р Наталия Сотирова}

Катедра „Етнология и балканистика“, Филологически факултет Югозападен университет „Неофит Рилски“ ул. „Иван Михайлов“ 66, 2700 Благоевград, България

$\square$ Nataliya Sotirova, $P h D$ Department of Ethnology and Balkan Studies, Faculty of Philology South-West University „Neofit Rilski““ 66 Ivan Mihaylov str. 2700 Blagoevgrad, Bulgaria 